\title{
Polio ウイルスの猿への経口感染試験
}

——牛 $\gamma$ ーグロブリンのウイルス血症に及ぼす影響—— 北岡正兒，三浦悌二，堀菊子，緒方隆幸，野村昌学

Masami Kitaoka, Teiji Miura, Kikuko Hori, Takayuki Ogata AND SHIGEkO NOMURA : STUDIES ON THE ORAL ADMINISTRATION OF POLIOMYELITIS VIRUSES IN MONKEYS. INFLUENCE, OF COW $\gamma$-GLOBULINS UPON THE VIREMIA.

[受稿：4月27日, 1954]

Polio に感染し等型的に発症するのは, 一般にはら イルスが経口的に摄取され，一旦腸管壁の細胞組織に 到遮してそこで増殖し,ついでそこから神経線維を伝 はり，最後に中枢神経系統に達し，中枢の神経細胞を 侵して病変を作り症状を起するのと推定されている。 そしてPolioの不顕性感染とは, 腸管内に侵入したウ イルスが，恐らくは腸管壁等では堌殖してもそれ以上

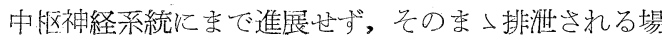
合であり，また不全型の感染とは踢管壁で増殖したり イルスの一部が中怄神経系統に到達するがそこに部分 的小病変を起す場合と見なされている。その推定の根 拠として，例えば polio 患者に見られる軖度の咽頭炎 は咽頭粘膜でのウイルスの増殖を想像させ，又扁桃腺 の摘出が激しい polio の発病を起すことも雄々認めら れている。

所が最近の組織培養法による研究は， polio ウイル スが神経以外の組織でも増殖し得ること学明にした。 また過去に执いて忠者の血液中から polio ウイルスを 証明することは極めて稀であつたが，最近に到り，猿 に経口的にウイルスを与兄ると比較的早期に猿の而液 中にウイルスが証明されている。彷つて惠者にも麻脾 出現前の時期に，ウイルス血症が起るであるうことが 推定され，委た事実患者の血液から直接 polio ウイル スが証明されたとの辩告も市り，又胎内感染例からも 人に持忷るウイルス血症の存在が推定されている。 かし，るしこのよ5にウイルス血症が発应前に起ると すれば，腸管壁のウイルスが中枢神経系統に到達する 経路として，必ずしる電子顕微鏡下で追求されたよ5 に神経線維を伝はらなくとも血行を介して全身感染を
起しそ結果として中枫神経系統に病変を起す, 89 考へられる。そして自然の感染発腚がもしウイルス直 症によるとすれば。 polioの免疫血清或は化学的の治 療䂆方の実現性に大きな望がかけられることになる。 しかし一方には古くから无神経線維を伝はつて行は れる感染経路説も未だ強く主張され，ウイルス血症は 神経系統の感染による二次的の結果で女るといはれ ている。

そこでジャワ哀を用い, polio ウイルスの中で第 2 型に属与る Lansing 䛈及文び東宗株を経口的に投与し， 猿の発症の有無，又血液や顀便中のウイルス証羽孝逐 日的に検傠した。更にウイルス経口投与を受けた猿に

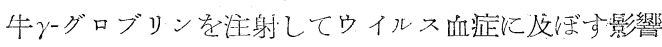
の検討を試みた。

\section{實 䌞 材 料}

猿：便用した15頭の猿はフィリッピンから輸大され た，体重およて 1.5〜 1.8kgのジャワ胲である・いづれ 子 polio 以外の実験に一度便用され, 全く発症しなか つたものである。

ウイルス株：Lansing 株は1947年 Dr. Hammon よ り分与を受け，当所に执いてマウス脳内に 8 代継代し たものである。東京株は1952年当所に稆いて分離同定 され、マウス脑内に 5 代継代したものである。

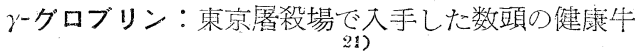
血清老混和し，Hess, Deutsch の方法に準じ, 低温工 タノール法によつて作つた自家製 $\gamma$ ーグロブリンでって の $\beta+\gamma$ グロブリンとしての純度は，雪気泳動法により 扮よそ70〜80\%无つた。

* 国立预防衛生研究所、リケッチァウイルス部 


\section{實 驗 方 法}

経口投与方法：Lansing 株又は東京株を脳内に接種

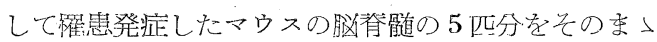
食塩水等を加えることなく乳剤として，一本のバナナ に挾えで猿に与え，猿が自由にこれを食べたことを每 回雠か力た。

猿の感染及び罹患の判定：ウイルスを経口的に与光 た猿が感染或は篗患したか否かを判定するため，毎日 検温して臨彇的所見を観察すると共にウイルス血症や 抗体出現等の有無について追求した。

血液及び賞便よりのウイルスの証明：ウイルスを食 ベた猿の和液及び筫便から，3〜6時間後，及び装日 より毎日24〜30間に亘りウイルスの証明が試みられ た。血液は䟝静䟿より採血され，直に 5 〜 匹のマウ スの脳内に接種された。筫便はペニシリン $500 \mathrm{u} / \mathrm{cc}$ 文 びストレプトマイシン $1 \mathrm{mg} / \mathrm{cc}$ を加えた食塩水で和よ そ20\%の乳戍となし，6000迥転20分間遠心してその上 清をそのまっマウス脳内に接種した。

分離ウイルスの同定：猿の血液或は黛便より分離さ れたウイルスの同定は，籊患マウスの症状，次代マウ スえの移殖及び既知標準血清による中和試験の成績に よつた。即ち定型的に発症した，或は死んだずでの

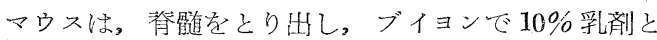
し，次代のマウス脳内に接種された。次代マウスが発 症すると。その脳春䯣はドライアイス中に保存され， 後になつて Lansing 株, Brunhilde 株及び Leon 株の 免疫血清による中和試験が行はれた。

中和試験の術式については既に発表したがっこっで 行つた方法は，分離ウイルス篗患マウスの脳内及び春 䯣の20\%乳郕穵作り。その遠心上清を予め Lansing, Brunhilde 放び Leon 株各ウィルスで充分に免疫した

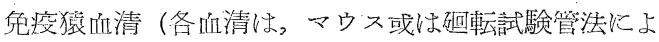
る人胎児組織培養法を用いた中和試験を行つて，それ ぞれの株に対してのみ 4.0 に及ぶ中和指数を有するこ とが確かめられた）の原液と等量に混合し，慗く公温 に放置してから各 4〜6 世宛のマウス䟛内に接種して 発淀と死亡を観察し，第 2 型の免疫血清によつての及 特異的に中和されていることを確わ奴た。

猿血清の中和試験：ウイルスを経口的に投与专当 放び経口投与後11〜94日目に採血し，Lansing 株に対 する中和試験を行つた。中和試験の術式は前に発表し た方法に準じた。 $\gamma$ グロブリンの注射： $\gamma$-グロブリンは $\mathrm{pH} 7.4$ の生

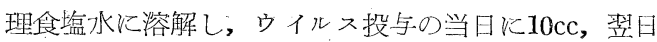
$5 \mathrm{cc}$, その䏠日 $10 \mathrm{cc}$, 計 $25 \mathrm{cc}$ 背部筋肉内に注射した。

\section{實 験 成 績}

\section{Lansing 株の経口投与試験}

1953年 1 月28日に 3 頭，本た 3 月23日に 6 頭，計 9

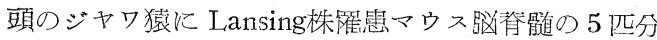
宛を食べれはた。

第1 回の 3 頭 (No. 74, 78, 79) の 万ち, 1 頡 (No,

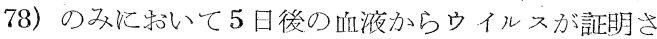
れたが，それ以外の血液及び凟便はすべて陰性に終つ た。

第 2 回の 6 頭の5ち 2 頭（No. 94，95）はウウイ ス投与の日から 3 日間牛 $\gamma$-グロブリンの筋肉内注射を 受けた。この2頭の血液及び冀便はすべて除性に終つ たが, 残りの4頭の5ち 1 頭 (No. 85) では 5 日後の 血液からウイルスが証明され，なた 3 時間後に 4 頭の 賴便を一括した材料からもウイルスが証明された（ Table 1).

\section{2. 東京株の経口投与試験}

マウス脳内で累代している Lansing株を経口的に与 えた歨験では，ウイルス血症の検出率が予期以上に低 かつたので，分離後間子ない，しか子その毒力が Lansing 株より幾分強いと思はれる同型の東京株を用 いて，経口投与試験を繰り返した。

1953年 4 月 25 日に 2 頭（No. 86, 89） 6 月24日に 4 頭 (No. 88, 89, 90, 91)，計 6 頭のジヤワ猿が用いら れた。櫻便からのウイルス分離は各回每に一括した材 料について行はれた。

第 1 回の 2 頭では，投与装日（No. 87）发び5日後 (No. 86) にウイルス直症が証明され，また翼便から も投与当日のものからのみウイルスが証明されたが他 は陰性であつた。

第 2 回の 4 頭では投与の翌日 (No. 88)，4 日後 ( No. 88)，支び5日後（No. 90）にウイルス向症が証 明れれ，また投与留日の翼便からもウイルスが証明さ れた。

これらの血液或は霬便から分離されたウイルスは Lansing 株免度血清により殆んど中和されたが， Brunhilde 及び Leon株血清では全く中和されなかつ た.

\section{3. 猿血清の中和試験}


Table 1. Virus isolation from blood and feces of monkeys following oral administration of poliomyelitis viruses "Lansing" and "Tokyo" strains

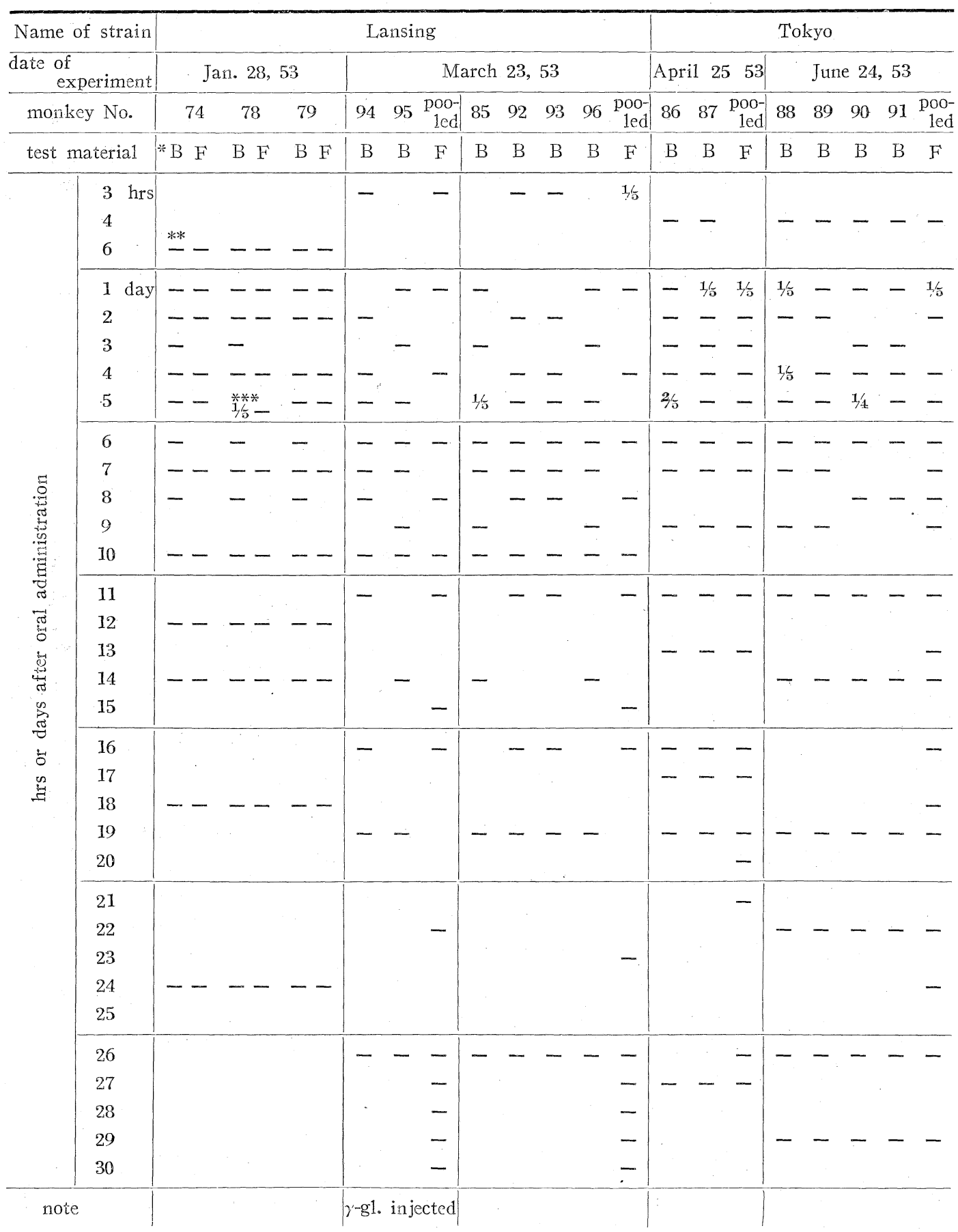
* B : blood,
F : feces
** negative in 5 inoculated mice

*** numerator : no. of positive mice, 
Table 2, Neutralization test of monkey sera before and after oral administration of poliomyelitis virus

\begin{tabular}{|c|c|c|c|c|c|c|}
\hline \multirow{3}{*}{$\begin{array}{l}\text { Name of } \\
\text { strain }\end{array}$} & \multirow{3}{*}{$\begin{array}{l}\text { date of oral } \\
\text { administration }\end{array}$} & \multirow{3}{*}{ monkey No. } & \multicolumn{4}{|c|}{ neutralization index } \\
\hline & & & \multirow{2}{*}{$\begin{array}{c}\text { before oral } \\
\text { administration } \\
\text { (1) }\end{array}$} & \multicolumn{2}{|c|}{ days after oral abminist. } & \multirow[b]{2}{*}{$(2)$ or $(3)-(1)$} \\
\hline & & & & $\begin{array}{c}15-25 \\
(2)\end{array}$ & $\begin{array}{c}30+ \\
(3)\end{array}$ & \\
\hline \multirow{4}{*}{ Lansing } & \multirow{4}{*}{ March $23^{\prime} 53$} & No. 93 & 1.3 & 0.8 & 0.5 & $*$ \\
\hline & & 94 & 1.0 & 0.6 & & - \\
\hline & & 95 & 1.1 & 1.4 & & 0.3 \\
\hline & & 96 & 1.3 & 0.8 & & - \\
\hline \multirow{6}{*}{ Tokyo } & \multirow{2}{*}{ April $25^{\prime} 53$} & 86 & 0.8 & 0.2 & & - \\
\hline & & 87 & 0.5 & 0.5 & 0.6 & 0.1 \\
\hline & \multirow{4}{*}{ June $24 ' 53$} & 88 & 0.3 & & 1.5 & 1.2 \\
\hline & & 89 & 0.5 & & 0.5 & 0 \\
\hline & & 90 & 0.4 & & 0.3 & - \\
\hline & & 91 & 0.3 & & 1.1 & 0.8 \\
\hline
\end{tabular}

$$
\text { ". (1) }>(2) \text { or }(3)
$$

第 2 表に示すようにウイルス投与の前後に中和試験 の行うことが出来た10頭の辡の血清について見ると, 経過と共に著明な中和抗体の上舅を示したものは無か つた。たよ゙ No. 88 の猿血清のみは中和指数で 1.2 の 上昂を見た。この猿のみは，た李たまウイルス血症が 2 回証明された唯一の猿で岁つた。

\section{總括と考按}

Lansing 株, 或は東京株を15頭の猿に経日的に与え たが 1 頭飞発症しなかつた。しかし15頭中6頭に杂い てウイルス折症が認められたことは，このことが発症 に效してて如何なる意義を有するに世上経口的に投与さ れた polio ウイルスが何らかの経路で血行中に侵入し たことを証明するものである。そのウイルス而症の時 期と頻度についてみると 1 日後（翌日）に2 例，4 文 び5日後にそれぞれ1 1 文び4例が陽性となり，その他 は专べて陰性であつた.いづれにしてもウイルス血症 が証明されながら，それが発症にまで進展しなかつた のは与えられたりイルスの量や毒力等との関連に扮い て，使用猿が Lansing株に対し，ウイルス投与前の血 中中和抗体が陰性であつたにしても，果して完全に哭 抵抗であつたか否かも問題となりらるであうう。

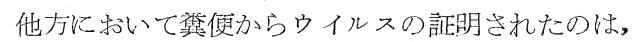
投与当日に 1 回, その翌日に 2 回，計 3 回のみで，そ れ以後はウィルス血症の陽性の時期でるずで陰性に 終つた。この成績は彷来穓便よりのウイルスの証明が
より長期間に亘つて成功している成績とは一致してい ない。

Fig. 1 Viremia and virus in stool after fecding of poliomyelitis virus on monkeys

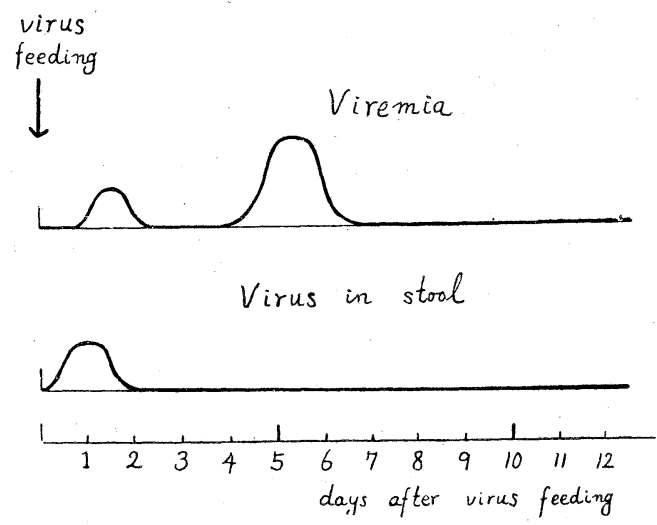

これらの関係を Fig. 1 に図示した。図からも明か のよ5に, ウイルス衈症には 2 , 筫便からのウイル スの証明には一つの山が認められた。

これらの零荚を総合すると，polio ウイルスの経口 投与と発症との間に和汁るウイルス血症の意義に関し て次の一仮説の想定が許され得るであるう。第一次口 イルス品症の山経口的に投与されたウィルスの一次 的血中侵入に基くものであり，第二次のそれは，第一 次の侵入に結果して起つた内臟に沶活るウイルス増殖 (内臓相) 後に, 増殖したウィルスが再び血行を介し 
て全身に撒布される為と解される。投与されたウイル スの体内侵入点は沶そらくは㸶頭粈膜や晹管壁である 5.中枢神経系統に和计るウイルスの堌殖（脊䯣相） が, 内臓相に併行して起つているるので女るのか, 或 は第二次ウイルス血症の結果として起るものであるの かは，果に慎重な病理組織学的及びウイルス学的検討 によつて決定さるべきで多ろう。この際, もし隻の感 受性が充分に高い場合には中枢神経系統にもウイルス が著明に增殖して病変をつくるに至り，polio の定型

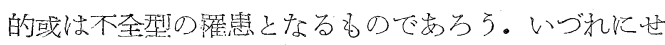
よ polioは，2回のウイルス血症により，内藏相に次 で脊咀相学星する一系統症虫であるとも考光られる。 そらだすると免疫血清或は化学薬用の投与による発 症阻止の可能性が考光られるし。又 polio の吱血昆虫 媒介説の可能性も全く否定出来なくなる・しかしなが ら，一部に称光られているよ5に，もし逆にウイルス 血症は答䯣相の原因ではなくそれれよつて二次的に 起つたるのであるならば,これらの可能性蛀く否定 されるものである。

謴便中にウイルスの証明されたのは第一次ウイルス 血症の時期に限られたが，それは罪患猿，或は患者の

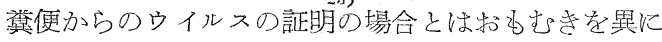
し，時間的には，経口的に投与されたりィルスがその

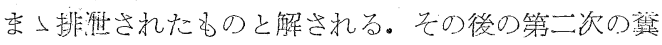
便内からのウイルスの証明（堌殖したウイルスの消化 管内一の排泄) は陰性に終つたが。乙れはこれらの猿 が㹥患しなかつた為にか，ウイルスの排注量がマウス を潅患させる程度に達しなかつた虎で岕るう。この害 からも腸管内のウイルス堌加はウイルン血症に先行さ れるもので女ると考光られる。

本金験で，Lansing 株を用いた場合は9頭中2頭 $(\gamma$ グロブリンを接種した 2 頭を除けけボ7頭中 2 頭，29\% ）に，東京株を用いた場合は6 頭中 4 頭，67\%にウィ ルス血症が証明された。恐らくは，東京株が Lansing 株よりもマウスに対する堽力が強く。しか子分離後間 もないためにウイルス而症を起し易いのではないかと 思はないかと思はれる。

上述の上うに, Lansing 株ウイルスを食べさ吠た2 頭の猿飞，25cc宛の $\gamma$-グロブリン孝筋注したところ，

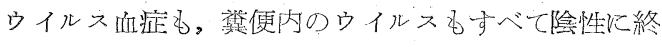
つた。しかし でも，ウイルス血症と，顀便内ウイルスが1回づ〉し か証明されていないのでこの所見のみからでは。
グロブリンの注射が，ウイルス血症と，劕便内一のウ イルス排酒とを芫全に阻止するものと結論するのは早 計で女る。この点について，もつとウイルス血症を起 し易い条件の下に，更に多数の猿について検討すべき である。

\section{結論}

1. ジャワ猿15頭を用い，9頭に Lansing株ウイル ス孝，6頭に東京株ウイルスを，バナナに挟み経口的 に投与したが1頭も発症しなかつた。

2. 15頭中 6 頭の猿に掠いて, ウイルス投与の当日 文は4〜5日後の血液からウイルスが証明された。

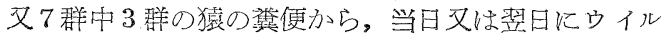
スが証明された。ウイルスの検出率は東京株を与えた 猿のちが。 Lansing 株を与充た場合よりも高いのでめ ろ5と思はれる。

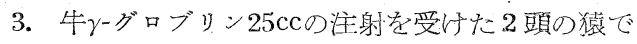
は, ウイルス血症も，翼便内のウイルス証明子陰性に 終つた。

4.これらの猿血清においては, 中和抗体の著しい 上帠は認められなかつだ。

\section{交献}

1) Howe, H. A. : Poliomyelitis. in Viral and Rickettsial Infections of Man. Lippincott, Philadelphia. 1948. 2) Horstmann, D. M. : Clinical aspects of acute poliomyelitis. Amer. Jour. Med., 6, 592-605, 1949. 3) Francis, T. Jr. Kri11, C. E., Toomey, J. A., and Mack, W. N., : Poliomyelitis following tonsilectomy in five members of a family. J. Amer. Med. Assn. 119, 1392-13 96, 1042. 4) Enders, J. F., Weller, T. H., and Robbins, F.C.: Cultivation of the Lansing strain of poliomyelitis virus in culturers of various human embryonic tissues. Science, 109, 85-87. 1949. 5) Wrard, R., Horstmann, D. M. and Melnick, J. L. : The isolation of poliomylitis virus from human extra-neural sources. IV Search for virus in the blood of patients. Jour. Clin. Invest., 25, 284-286, 1946.6 6) Horstmann, D. M., : Poliomyelitis virus in the blood of orally infected monkeys and chimpanzees. Proc. Soc. Exp. Biol. \& Med, 79, 417-419, 1952. 7) Bodian, D. : Experimental studies on passive 
immunization against poliomyelitis, III. Passive active immunization and pathogenesis after virus feeding in chimpanzees. Amer, Jour. Hyg., 58, 81-100, 1953. 8) Bodian, D, : A reconsideration of the pathogenesis of poliomyelitis. Amer. Jour. Hyg., 55, 414-438, 1952. 9) Nishizawa, Y. and Okano, K.: The significance of viremia in the pathway of infection of poliomyelitis, Arch, ped. New York., 70, 71-80, 1953. 10) Kausche, G. A., and Bender, A. : Zurkeuntnis des poliomyelitis virus. Arch, f. d. ges. virus forsch. 4, 217-223, 1951. 11) Koprowski, H., Norton, T. W., and McDermott, W.. : Isolation of poliomyelitis virus from human serum by direct inoculation into laboratory mouse. Pub. Health Rep. 62, 1467-1476., 1947. 12) Horstmann, D. M. and McCollum, R. W. : Poliomyelitis virus in human blood during the "Minor illness" and the asymptomatic infection. Proc. Soe. Exp. Biol., Med, 82, 434-437, 1953. 13) Mule, F. : La viremia della malattia di Heine Medin. Rend. 1st. super. Sanitā, 15, 220-225, 1052. 14) Faber, H. K., and Baskin, J. L.: polio:nyelitis in the newborn. Amer. Jour. Dis. child., 80, 999-1001, 1950. 15) Jhonson, J. F., and Stimson, P. M. : Clinical poliomyelitis in the early neonatal period. $R$. port of a case. Jour. Pediat. 40, 733-737, 1952. 16) De Robertis, E, and Schmitt, F. O.: An electron microscope study of nerves infected with human poliomyelitis virus. Jour. Exp. Med., 90, 283290, 1949. 17) Bodian, D., and Howe, H, A, : Neuronal pathways as determining factors in dissemination of poliomyelitis in the central nervous system. Proc. Soc. Eixp. Biol. \& Med., 41, 540 -545 1939. 18) Faber, H. K. and Silverberg, R. J. : Studies on entry and egress of poliomyelitis infection. $\mathbb{N}$. Centrifugal spread of the virus into peripheral nerve: with notes on its possible implications. Jour. Exp. Med., 97, 455-465, 1953.19 ) Armstrong, C. : The experimental transmission of poliomyelitis to the eastern cotton rat Sigmodon Hispidus Pub. Health Rep., 54, 1719-1721, 1939.20）北岡正見,三浦悌二,班子：急性灰白髓炎 \イルス乘京株の分離，医学々生物学，26，185188, 1953. 21) Hess, E, L., and Deulsch, H. F. : Biophysical studies of blood plasma proteins. VIII. separation and properties of the $\gamma$-globulins of the sera of normal cows. Jour. Amer. Chem. Soc., 70, 84-88, 1948. 22) Kitaoka, M., and Miura, T. : The neutraliziation test of normal and convalescent human sera in Tokyo, against the mouseadapted poliomyelitis virus "Lansing" strain. Jap. Med. Jour., 2, 285-294, 1949. 23) Horstmann, D. M., Melnick, J. L., and wenner, $H_{\text {. }}$ A. : The isolation of poliomyelitis virus from human extraneural sources. III. persistence of virus in stools after acute infection. J. Clin. Invest., 25, 278-283, 1946. 